\title{
Carter and the test of energy
}

For the first time since the Arab oil embargo, the United States Government seems ready to consider adopting a comprehensive energy policy, one which involves efforts to curb the nation's profligate consumption as well as attempts to step up domestic energy supplies. Such a policy is long overdue, but it will severely test the will and the political skills of the new Carter Administration to put it into practice.

Although both Mr Nixon and Mr Ford paid a good deal of lip service to the need for energy conservation during their terms in office, their energy policies consisted essentially of throwing large sums of money into the supply side of the energy equation. Indeed, when $\mathrm{Mr}$ Nixon launched his infamous Project Independence, he even insisted on making absurd claims that American technology would free the United States from relying on imported oil to meet its energy needs by 1980 . The demand side of the equation was badly neglected, perhaps for understandable reasons.

The United States has grown up with cheap power, with the ethic that bigger means better, and with the philosophy that the government has little right to meddle in the workings of the so-called free market. All that would have to be changed if a serious attempt is made to curtail energy demand. Mr Nixon, who was already under siege when the oil embargo struck, probably lacked the political ability to pursue effective conservation policies-in any case, he didn't make much of an effort. And Mr Ford suffered the handicaps of being an unelected President who belonged to a different political party from the one which controlled the Congress and who had an abiding faith in the free market.

President Carter may be different. His campaign rhetoric was peppered with promises to develop an energy policy, and he has repeatedly warned that it will require considerable 'sacrifice' from the American people. He also comes to office riding a tide of goodwill and-perhaps most important - this year's extraordinary winter has provided a more vivid argument for conservation than a thousand Presidential statements. If Carter doesn't manage to put an energy policy into effect, it would be a serious indictment of his Administration's political ability.

So far, Carter's efforts are promising. The first major instalment of his energy policy came last week when he proposed legislation to consolidate most of the federal government's sprawling energy bureaucracies into one Cabinet-level department under the direction of James Schlesinger, former head of the Atomic Energy Commission, the Central Intelligence Agency and the Department of Defense. Though the proposed arrangement is eminently sensible, the bill would clump together agencies and pro- grammes which are now handled by different Congressional committees. Some jurisdictional disputes may therefore delay passage of the Bill, but approval is nevertheless anticipated.

Once in place, the Department of Energy should be in a better position to plan both conservation and supply policies. That's where the second instalment of Carter's energy policy comes in. He has promised to unveil a comprehensive energy plan on 20 April, with particular emphasis on conservation. A preview of at least some of the elements of that policy was provided last month when Carter sent Congress a number of revisions to the budget proposals which $\mathrm{Mr}$ Ford left behind.

As far as research and development are concerned, Carter's policy will concentrate on efforts likely to produce results in the relatively near term. Thus, long term efforts such as the breeder reactor programme, nuclear fusion efforts, and the development of large scale solar power plants, would be cut back and the money reprogrammed into energy conservation and into efforts to get alreadydeveloped technologies, such as solar heaters, into the market-place. The justification for such moves is that it will probably be more difficult to commercialise new energy technologies than to develop them, and government incentives are required to feed the growth of, say, a solar energy industry. Those arguments are likely to find favour in Congress.

As for curtailing energy use, the Administration can pursue only a limited number of technological fixes, such as forcing the automobile industry to make more efficient cars and encouraging the use of battery-driven vehicles. But the most effective energy conservation measure would be to increase energy prices through the use of federal energy prices through the use of federal energy taxes.

Such a move would, however, be very difficult to get through the Congress and it would also have to be coupled with a system for returning the tax revenues back into the economy, preferably in a manner which would mitigate the burden on low income groups. It is estimated that every cent of tax on a gallon of gasoline would raise about $\$ 1,000$ million in revenue; a large tax could have a depressing effect on the economy. One idea which is being floated is to return some of the tax revenues into energy-saving measures such as income tax credits for home insulation, construction of mass transit systems and so on. In any case, the Carter Administration has already begun to leak the fact that it is considering raising energy prices in order to prepare the American public for the inevitability of a long overdue move away from the present artificially low prices of energy. 